\title{
Synthesis, Growth, Crystal Structure and Characterization of the o-Toluidinium Picrate
}

\author{
Kandasamy Mohana Priyadarshini ${ }^{1}$, Angannan Chandramohan ${ }^{1 *}$, Thangarak Uma Devi ${ }^{2}$ \\ ${ }^{1}$ Department of Chemistry, Sri Ramakrishna Mission Vidyalaya College of Arts and Science, Coimbatore, India; ${ }^{2}$ Department of \\ Physics, Government Arts College for Women, Pudukottai, India. \\ Email: ${ }^{*}$ dracmsrmv20@gmail.com
}

Received July 23 ${ }^{\text {rd }}, 2013$; revised July August 23 ${ }^{\text {rd }}, 2013$; accepted August 30 ${ }^{\text {th }}, 2013$

Copyright (C) 2013 Kandasamy Mohana Priyadarshini et al. This is an open access article distributed under the Creative Commons Attribution License, which permits unrestricted use, distribution, and reproduction in any medium, provided the original work is properly cited.

\begin{abstract}
A new organic charge transfer molecular complex salt of o-toluidinium picrate (OTP) was synthesised and the single crystals were grown by the slow solvent evaporation solution growth technique using methanol as a solvent at room temperature. Formation of the new crystal has been confirmed by single crystal X-ray diffraction (XRD) and NMR spectroscopic techniques. The crystal structure determined by single crystal X-ray diffraction indicates that both the cation and the anion are interlinked to each other by three types of intermolecular hydrogen bonds, namely $\mathrm{N}(4)-\mathrm{H}(4 \mathrm{~A}) \cdots \mathrm{O}(7), \mathrm{N}(4)-\mathrm{H}(4 \mathrm{~B}) \cdots \mathrm{O}(5)$ and $\mathrm{N}(4)-\mathrm{H}(4 \mathrm{C}) \cdots \mathrm{O}(7)$. The title compound (OTP) crystallizes in monoclinic crystal system with the centrosymmetric space group $\mathrm{P} 2_{1} / \mathrm{c}$. Fourier transform infrared (FT IR) spectral analysis was used to confirm the presence of various functional groups in the grown crystal. The optical properties were analyzed by the UV-Vis-NIR and fluorescence emission studies.
\end{abstract}

Keywords: Single Crystal; Organic Molecules; Solution Growth; X-Ray Diffraction; Characterization; Nonlinear Optical

\section{Introduction}

The organic materials with aromatic ring, which are of great interest for second and third-order nonlinear optical applications due to their high nonlinearity, high optical damage threshold and their ultrafast, almost purely electronic response. Based on the concepts of the molecular and crystal engineering, the organic molecules offer many possibilities to tailoring the substances with desired properties through optimization of the microscopic hyperpolarizabilities and the incorporation of the molecules in a crystalline lattice [1-4]. Mulliken suggested that the charge transfer interactions from two aromatic molecules can arise from the transfer of an electron from Lewis base to Lewis acid and these complexes have attracted great attention for nonlinear optical materials. Generally, proton transfer interactions between electron donor and electron acceptor molecules absorb radiation in the visible region leading to the formation of intensely colored charge transfer complexes [5-10]. Picric acid forms crystalline picrates of various organic molecules through ionic and hydrogen bonding and $\pi-\pi$ interactions and the

"Corresponding author. presence of phenolic $\mathrm{OH}$ in the picric acid favors the formation of the salts with various organic bases [11]. The formation of charge transfer complex depending on the nature of the donor-acceptor system and the orientation of anionic and cationic species facilitates the formation of expected $\mathrm{N}-\mathrm{H} \cdots \mathrm{O}$. hydrogen bonds between amino hydrogen and phenolic oxygen [12]. It has been reported that intramolecular hydrogen bonding interactions are absent in most of the picrate salts [13] and picric acid derivatives are interesting candidates, as the presence of phenolic $\mathrm{OH}$ and electron withdrawing nitro groups favors the formation of salts with various organic bases such as N,N-dimethylanilinium picrate [11], 3-Methyl aniliniumpicrate [14], 2-Chloroanilinium picrate [15], Anilinium picrate [16], p-toluidinium picrate [13], 8hydroxyquinolinium picrate [17], 1,3-Dimethylurea dimethyl ammonium picrate [18], N,N-Dimethyl anilinium picrate [19] have already been reported. The title salt crystallizes in the monoclinic crystal system with centrosymmetric space group $\mathrm{P} 2{ }_{1} / \mathrm{c}$, an analogue of p-Toluidinium picrate. In the present work, we report the synthesis, crystal growth, structural, spectral and optical studies of o-toluidinium picrate single crystal. 


\section{Experimental Procedure}

\subsection{Material Synthesis}

Analar grade o-toluidine $(1.07 \mathrm{~g}, 0.01 \mathrm{~mol})$ and Picric acid $(2.29 \mathrm{~g}, 0.01 \mathrm{~mol})$ were dissolved in pure methanol separately in equimolar ratio and the two solutions were mixed together. The solution was stirred well for about one hour, when a yellow colored crystalline precipitate of the charge transfer complex salt of o-toluidinium picrate was obtained as a result of the acid-base reaction between picric acid and o-toluidine. The precipitate was filtered off and recrystallised many times in methanol to enhance the degree of purity of the product. The reaction involved is illustrated in the Scheme 1.

\subsection{Growth and Characterization of OTP Single Crystals}

A saturated methanolic solution of OTP was prepared, stirred well for about five hours and filtered through a quantitative whatmann 41 grade filter paper to eliminate the unwanted suspended impurities present in the solution. The clear filtrate so obtained was kept aside unperturbed in a dust-free room for the growth of single crystals. Well-defined, yellow colored crystals were collected at the end of the 8th day. The photograph of as-grown crystals of OTP is shown in Figure 1. The grown OTP crystal was subjected to various characterization techniques like ${ }^{1} \mathrm{H}$ and ${ }^{13} \mathrm{C}$ NMR spectral analyses, single crystal X-ray diffraction studies, Fourier transform infrared (FT IR), UV-Vis-NIR spectral analysis and Fluorescence emission studies. The detailed results are presented in the following sections.
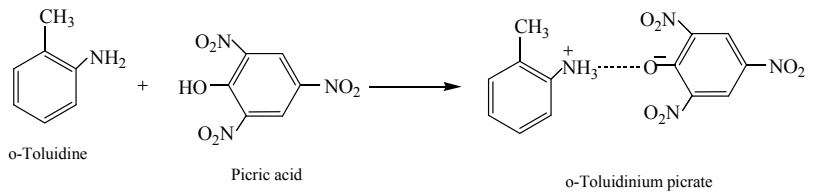

Scheme 1. Reaction mechanism of o-toluidinium picrate.

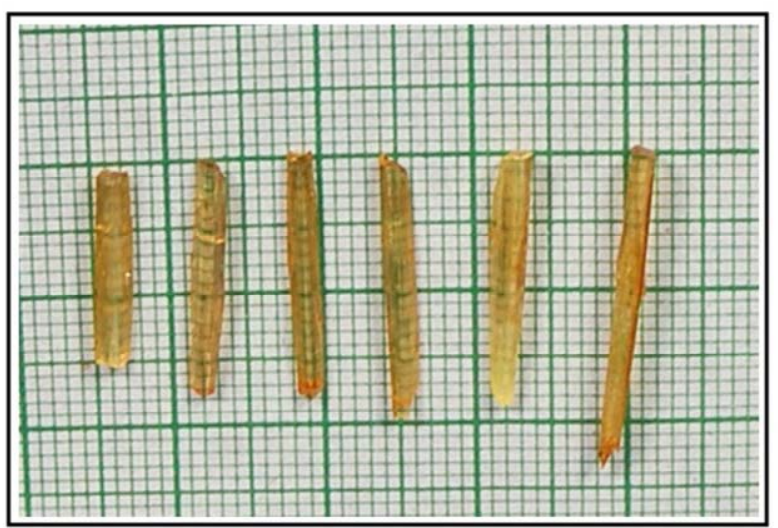

Figure 1. As-grown single crystals of OTP.

\section{Results and Discussion}

\subsection{Nuclear Magnetic Resonance Studies}

The ${ }^{1} \mathrm{H}$ and ${ }^{13} \mathrm{C}$ NMR spectra were recorded using the BRUKER AVANCE III $500 \mathrm{MHz}$ (AV 500) spectrometer with TMS as the internal reference standard and DMSO as the solvent.

The ${ }^{1} \mathrm{H}$ NMR spectrum of the title crystal (Figure 2) shows four proton signals indicating the presence of four different proton environments in the OTP crystal. The broad hump appearing at $\delta 9.66 \mathrm{ppm}$ is assigned to the highly deshielded ${ }^{+} \mathrm{NH}_{3}$ protons of o-toluidinium moiety. The intense singlet signal appearing at $\delta 8.61 \mathrm{ppm}$ has been assigned to $\mathrm{C} 3$ and $\mathrm{C} 5$ aromatic protons of the same kind in picrate moiety. The complex multiplet signal centered at $\delta 7.32 \mathrm{ppm}$ is arising due to the overlap between two triplets attributed to $\mathrm{C} 4$ and $\mathrm{C} 5$ aromatic protons and two doublets due to $\mathrm{C} 3$ and $\mathrm{C} 6$ aromatic protons of o-toluidinium moiety in the salt. The triplet and doublet signals coalesce into a multiplet due to the closeness of the coupling constant values. The singlet signal at $\delta$ $2.32 \mathrm{ppm}$ has been assigned to the methyl protons of otoluidinium moiety.

The ${ }^{13} \mathrm{C}$ NMR spectrum of OTP is depicted in Figure 3. The appearance of eleven distinct peaks in the spectrum establishes the molecular structure of the OTP complex salt. The weak carbon signal at $\delta 161.30 \mathrm{ppm}$ owes to the ipso carbon (C1) of picrate moiety. The $\mathrm{C} 2$ and $\mathrm{C} 6$ aromatic carbon atoms of the same kind in picrate moiety appear at $\delta 142.28 \mathrm{ppm}$. The highly intense peak at $\delta 125.70 \mathrm{ppm}$ is due to $\mathrm{C} 3$ and $\mathrm{C} 5$ aromatic carbon atoms of the same kind in picrate moiety. The weak signal at $\delta 124.89 \mathrm{ppm}$ is assigned to $\mathrm{C} 4$ carbon atom of the same moiety in the complex salt. The peaks appearing at $\delta 132.03,131.83,131.12,128.66,127.63$ and $123.59 \mathrm{ppm}$ have been assigned respectively to $\mathrm{C} 2$, $\mathrm{C} 3, \mathrm{C} 4, \mathrm{C} 5, \mathrm{C} 6$ and $\mathrm{C} 1$ carbon atoms in o-toluidinium moiety in the complex. The signal at $\delta 17.23 \mathrm{ppm}$ is attributed to the methyl carbon of o-toluidinium moiety.

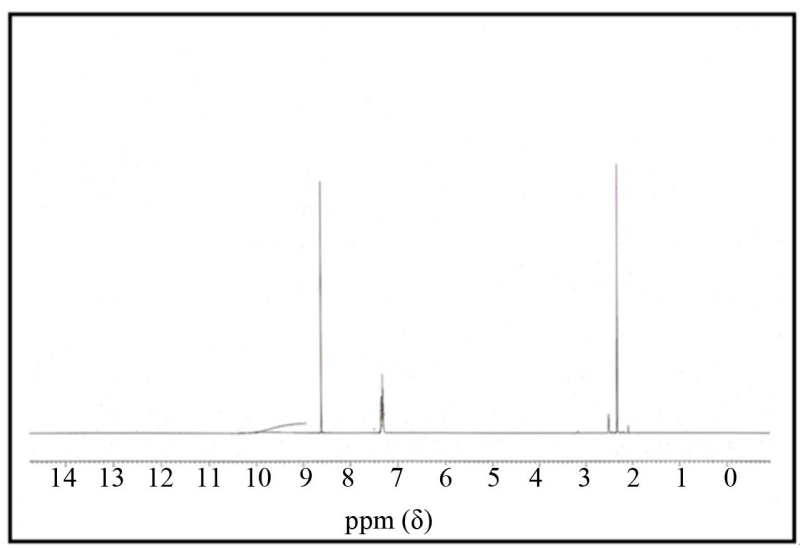

Figure 2. ${ }^{1} \mathrm{H}$ NMR spectrum of OTP. 


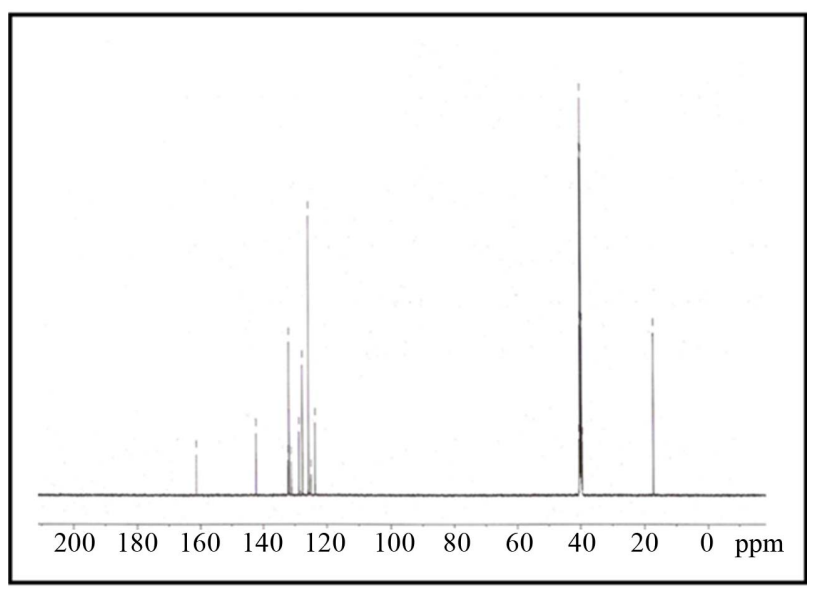

Figure $3 .{ }^{13} \mathrm{C}$ NMR spectrum of OTP.

\subsection{FT-IR Spectroscopy}

The characteristic vibrational frequencies of the functional groups of OTP are identified from the fourier transform infrared (FT-IR) spectrum recorded in the range of $4000-400 \mathrm{~cm}^{-1}$ employing Perkin-Elmer FT-IR spectrometer by using the $\mathrm{KBr}$ pellet technique. The formation of charge transfer complex during the acidbase interaction of o-toluidine with picric acid is strongly evidenced through the realization of important bands of donor and acceptor in the resultant spectrum of the complex salt (Figure 4). The absorption at $3194 \mathrm{~cm}^{-1}$ is due to the ${ }^{+} \mathrm{N}-\mathrm{H}$ stretching vibration. The absorption band at $3060 \mathrm{~cm}^{-1}$ corresponds to aromatic C-H asymmetric stretching vibration. The broad absorption bands in the region 2940 to $2813 \mathrm{~cm}^{-1}$ are due to the overlapping of $\mathrm{C}-\mathrm{H}$ asymmetric and symmetric stretching vibration of methyl group and aromatic $\mathrm{C}-\mathrm{H}$ symmetric stretching vibration. The absorptions at 1535 and $1359 \mathrm{~cm}^{-1}$ confirm the asymmetric and symmetric stretching vibrations of $\mathrm{NO}_{2}$ group respectively. The $\mathrm{C}-\mathrm{O}$ stretching vibration is observed at $1192 \mathrm{~cm}^{-1}$. The band at $836 \mathrm{~cm}^{-1}$ is due to $\mathrm{C}-\mathrm{N}$ stretching vibration. The presence of $\mathrm{C}=\mathrm{C}$ stretching vibration of aromatic ring is revealed from the absorption bands at 1606,1570 and $1479 \mathrm{~cm}^{-1}$. The assignment is in very close agreement with data of the complex salts reported already [7-9].

\subsection{Single Crystal X-Ray Diffraction Studies}

Single crystal XRD analysis for the grown o-toluidinium picrate has been carried out to identify the unit cell parameters and the crystal structure using "ENRAF (BRUKER) NONIUS CAD4" diffractometer with graphite monochromated $\mathrm{MoK} \alpha$ radiation $(\lambda=0.71073 \AA)$. The structure was solved by direct methods procedure as implemented in SHELXS 97 [20] program. Cell refinement and data reduction were carried out using SAINT program. All the hydrogen atoms were fixed geometri- cally and allowed to ride on their parent atoms. All non-hydrogen atoms were refined using anisotropic displacement parameters.

The crystal structure analyses of OTP reveals that OTP crystallized in a monoclinic crystal structure with centrosymmetric space group $\mathrm{P} 2 / \mathrm{c}$, and the unit cell parameters are $\mathrm{a}=11.6475(2) \AA, \mathrm{b}=16.4763(5) \AA, \mathrm{c}=$ 7.5702(4) Å. Table 1 summarizes the crystal data, intensity data collection and refinement details for the OTP single crystals. The selected bond lengths and bond angles of OTP charge transfer complex salt are given in Tables 2 and 3 respectively. The protonation on the N1 site of the cation is confirmed from $\mathrm{C}-\mathrm{N}$ bond distances and C-N-C bond angles. All the bond distances and bond angles of the two molecules in the asymmetric unit are agreed with each other. The crystal structure of OTP consists one molecule each of o-toluidinium cation and picrate anion. The ORTEP of the charge transfer complex OTP is clearly shown in the Figure $\mathbf{5}$ and the atom numbering scheme adopted. A well-defined yellow colour single crystal of OTP with dimension $0.30 \times 0.20 \times$ $0.20 \mathrm{~mm}$ was selected for diffraction analysis. A total of 12528 reflections (2541 Unique, $\mathrm{R}(\mathrm{int})=0.0239)$ were collected by using $\omega / 2 \theta$ scan mode at $293(2) \mathrm{K}$ in the range of $2.15^{\circ}<\theta<25^{\circ}$ with the index ranges $-13<=\mathrm{h}$ $=13,-19<=\mathrm{k}<=19,-7<=1<=9$. The refinement converged to final R-factor of $0.04 \%$. The packing diagram (Figure 6) indicates the existence of intermolecular hydrogen bonds in the three dimensional network between the constituent molecules. The structure is based on asymmetric part of o-Toluidinium picrate which contains 2-methyl anilinium cation and picrate anion connected by three intermolecular $\mathrm{N}-\mathrm{H} \cdots \mathrm{O}$ hydrogen bonds with a donor-acceptor distance of 2.7697(19), 2.853(2) and 2.762(2) $\AA$. The corresponding data for the H-bonds are listed in Table 4. In the charge transfer complex of OTP, the carbon skeleton of the anionic picrate species

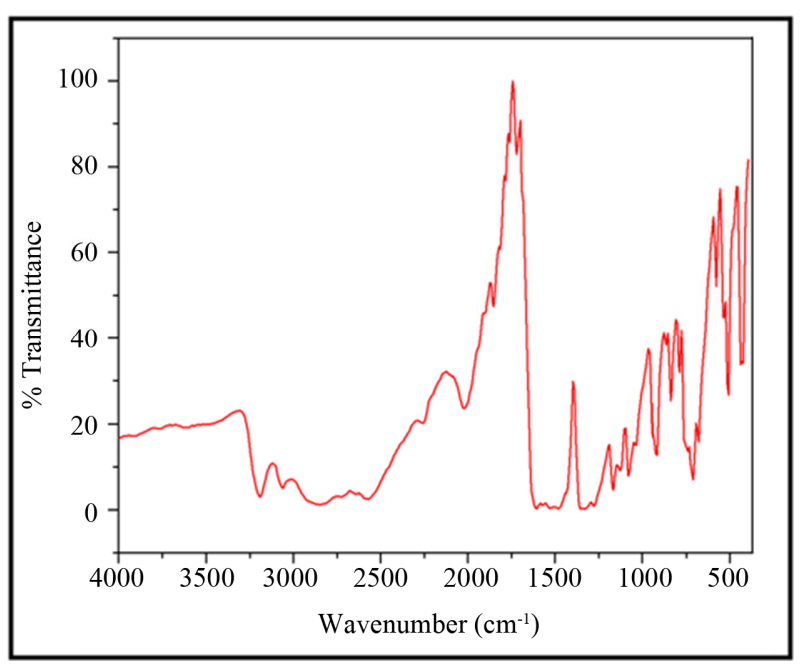

Figure 4. FT-IR spectrum of OTP. 
Table 1. Crystallographic data for OTP.

\begin{tabular}{|c|c|}
\hline Empirical formula & $\mathrm{C}_{13} \mathrm{H}_{12} \mathrm{~N}_{4} \mathrm{O}_{7}$ \\
\hline Formula weight & 336.27 \\
\hline Temperature & $293(2) \mathrm{k}$ \\
\hline Wavelength & $0.71073 \AA$ \\
\hline Crystal system, space group & Monoclinic, $\mathrm{P} 2_{1} / \mathrm{c}$ \\
\hline Unit cell dimensions & $\begin{array}{c}\mathrm{a}=11.6475(2) \AA, \alpha=90^{\circ} \mathrm{b}= \\
16.4763(5) \AA, \beta=94.1980(10)^{\circ} \\
\mathrm{c}=7.5702(4) \AA, \gamma=90^{\circ}\end{array}$ \\
\hline Volume & $1448.88(9) \AA^{3}$ \\
\hline Z, Calculated density & $4,1.542 \mathrm{Mg} / \mathrm{m}^{3}$ \\
\hline Absorption coefficient & $0.128 \mathrm{~mm}^{-1}$ \\
\hline $\mathrm{F}(000)$ & 696 \\
\hline Crystal size & $0.30 \times 0.20 \times 0.20 \mathrm{~mm}$ \\
\hline Theta range for data collection & 2.15 to $25.00 \mathrm{deg}$ \\
\hline Limiting indices & $\begin{array}{c}-13<=\mathrm{h}<=13,-19<=\mathrm{k}<=19, \\
-7<=1<=9\end{array}$ \\
\hline Reflections collected/unique & $12528 / 2541[\mathrm{R}(\mathrm{int})=0.0239]$ \\
\hline Completeness to theta $=25.00$ & $99.9 \%$ \\
\hline Absorption correction & Semi-empirical from equivalents \\
\hline Max. and min. transmission & 0.9924 and 0.9245 \\
\hline Refinement method & Full-matrix least-squares on $\mathrm{F}^{2}$ \\
\hline Data/restraints/parameters & $2541 / 0 / 220$ \\
\hline Goodness-of-fit on $\mathrm{F}^{2}$ & 1.046 \\
\hline Final $R$ indices $[\mathrm{I}>2 \operatorname{sigma}(\mathrm{I})]$ & $\mathrm{R} 1=0.0402, \mathrm{wR} 2=0.1084$ \\
\hline $\mathrm{R}$ indices (all data) & $\mathrm{R} 1=0.0468, w \mathrm{R} 2=0.1152$ \\
\hline Extinction coefficient & $0.0042(11)$ \\
\hline Largest diff. peak and hole & 0.382 and $-0.264 \mathrm{e} . \AA^{-3}$ \\
\hline
\end{tabular}

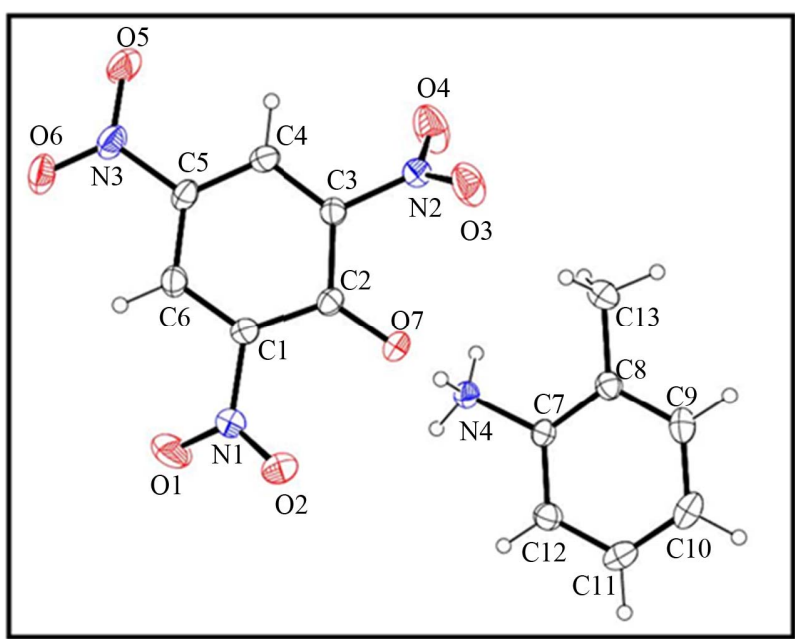

Figure 5. ORTEP diagram of OTP.
Table 2. Selected bond lengths in OTP (Å).

\begin{tabular}{ll}
\hline $\mathrm{C}(1)-\mathrm{C}(6)$ & $1.374(2)$ \\
$\mathrm{C}(1)-\mathrm{C}(2)$ & $1.432(2)$ \\
$\mathrm{C}(1)-\mathrm{N}(1)$ & $1.461(2)$ \\
$\mathrm{C}(2)-\mathrm{O}(7)$ & $1.270(2)$ \\
$\mathrm{C}(2)-\mathrm{C}(3)$ & $1.429(2)$ \\
$\mathrm{C}(3)-\mathrm{C}(4)$ & $1.365(2)$ \\
$\mathrm{C}(3)-\mathrm{N}(2)$ & $1.462(2)$ \\
$\mathrm{C}(4)-\mathrm{C}(5)$ & $1.386(3)$ \\
$\mathrm{C}(5)-\mathrm{C}(6)$ & $1.380(3)$ \\
$\mathrm{C}(5)-\mathrm{N}(3)$ & $1.447(2)$ \\
$\mathrm{C}(7)-\mathrm{C}(12)$ & $1.380(2)$ \\
$\mathrm{C}(7)-\mathrm{C}(8)$ & $1.386(2)$ \\
$\mathrm{C}(7)-\mathrm{N}(4)$ & $1.470(2)$ \\
$\mathrm{C}(8)-\mathrm{C}(9)$ & $1.391(3)$ \\
$\mathrm{C}(8)-\mathrm{C}(13)$ & $1.503(3)$ \\
$\mathrm{C}(9)-\mathrm{C}(10)$ & $1.376(3)$ \\
$\mathrm{C}(10)-\mathrm{C}(11)$ & $1.375(3)$ \\
$\mathrm{C}(11)-\mathrm{C}(12)$ & $1.380(3)$ \\
$\mathrm{C}(13)-\mathrm{H}(13 \mathrm{~A})$ & 0.9600 \\
$\mathrm{~N}(1)-\mathrm{O}(1)$ & $1.216(2)$ \\
$\mathrm{N}(1)-\mathrm{O}(2)$ & $1.221(2)$ \\
$\mathrm{N}(2)-\mathrm{O}(4)$ & $1.209(2)$ \\
$\mathrm{N}(2)-\mathrm{O}(3)$ & $1.213(2)$ \\
$\mathrm{N}(3)-\mathrm{O}(6)$ & $1.215(2)$ \\
$\mathrm{N}(3)-\mathrm{O}(5)$ & $\mathrm{H}(4 \mathrm{~A})$ \\
\hline & \\
\hline & \\
\hline
\end{tabular}

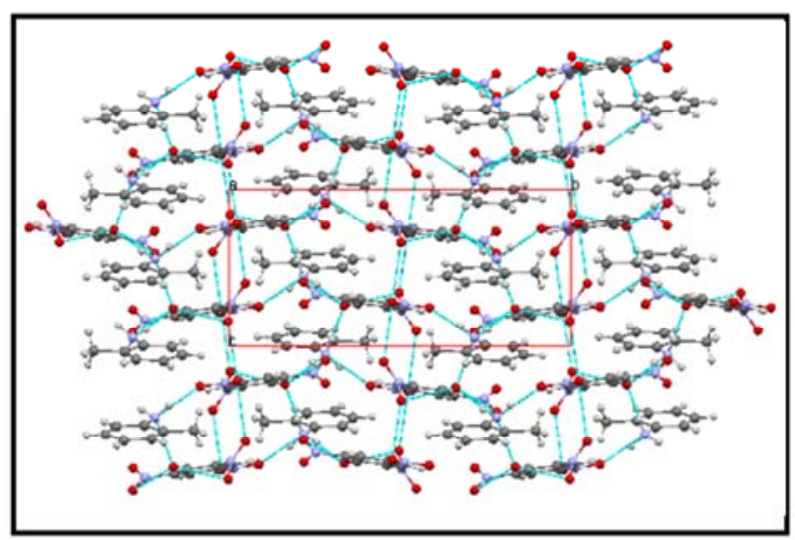

Figure 6. Packing arrangement of molecules showing intermolecular $\mathrm{N}-\mathrm{H} \cdots \mathrm{O}$ hydrogen bonding interactions and $\pi-\pi$ interactions viewed down in the c-axis. 
Table 3. Selected bond angles in OTP $\left({ }^{\circ}\right)$.

\begin{tabular}{|c|c|}
\hline $\mathrm{C}(6)-\mathrm{C}(1)-\mathrm{C}(2)$ & $124.17(16)$ \\
\hline $\mathrm{C}(6)-\mathrm{C}(1)-\mathrm{N}(1)$ & $116.84(16)$ \\
\hline $\mathrm{C}(2)-\mathrm{C}(1)-\mathrm{N}(1)$ & $118.88(15)$ \\
\hline $\mathrm{O}(7)-\mathrm{C}(2)-\mathrm{C}(3)$ & $122.26(15)$ \\
\hline $\mathrm{O}(7)-\mathrm{C}(2)-\mathrm{C}(1)$ & $125.48(16)$ \\
\hline $\mathrm{C}(3)-\mathrm{C}(2)-\mathrm{C}(1)$ & $112.14(14)$ \\
\hline $\mathrm{C}(4)-\mathrm{C}(3)-\mathrm{C}(2)$ & $125.28(15)$ \\
\hline $\mathrm{C}(4)-\mathrm{C}(3)-\mathrm{N}(2)$ & $117.71(15)$ \\
\hline $\mathrm{C}(2)-\mathrm{C}(3)-\mathrm{N}(2)$ & $116.99(14)$ \\
\hline $\mathrm{C}(3)-\mathrm{C}(4)-\mathrm{C}(5)$ & $118.03(16)$ \\
\hline$C(6)-C(5)-C(4)$ & $121.50(16)$ \\
\hline $\mathrm{C}(6)-\mathrm{C}(5)-\mathrm{N}(3)$ & $119.09(16)$ \\
\hline $\mathrm{C}(4)-\mathrm{C}(5)-\mathrm{N}(3)$ & $119.37(16)$ \\
\hline$C(1)-C(6)-C(5)$ & $118.77(16)$ \\
\hline$C(12)-C(7)-C(8)$ & $122.89(16)$ \\
\hline $\mathrm{C}(12)-\mathrm{C}(7)-\mathrm{N}(4)$ & $118.12(15)$ \\
\hline $\mathrm{C}(8)-\mathrm{C}(7)-\mathrm{N}(4)$ & $118.98(15)$ \\
\hline $\mathrm{C}(7)-\mathrm{C}(8)-\mathrm{C}(9)$ & $116.38(17)$ \\
\hline $\mathrm{C}(7)-\mathrm{C}(8)-\mathrm{C}(13)$ & $122.73(16)$ \\
\hline $\mathrm{C}(9)-\mathrm{C}(8)-\mathrm{C}(13)$ & $120.89(17)$ \\
\hline $\mathrm{C}(10)-\mathrm{C}(9)-\mathrm{C}(8)$ & $121.68(18)$ \\
\hline $\mathrm{C}(11)-\mathrm{C}(10)-\mathrm{C}(9)$ & $120.34(18)$ \\
\hline $\mathrm{C}(10)-\mathrm{C}(11)-\mathrm{C}(12)$ & $119.74(18)$ \\
\hline $\mathrm{C}(11)-\mathrm{C}(12)-\mathrm{C}(7)$ & $118.96(17)$ \\
\hline $\mathrm{C}(8)-\mathrm{C}(13)-\mathrm{H}(13 \mathrm{~A})$ & 109.5 \\
\hline $\mathrm{H}(13 \mathrm{~A})-\mathrm{C}(13)-\mathrm{H}(13 \mathrm{~B})$ & 109.5 \\
\hline $\mathrm{O}(1)-\mathrm{N}(1)-\mathrm{O}(2)$ & $123.16(18)$ \\
\hline $\mathrm{O}(1)-\mathrm{N}(1)-\mathrm{C}(1)$ & $118.20(17)$ \\
\hline $\mathrm{O}(2)-\mathrm{N}(1)-\mathrm{C}(1)$ & $118.65(16)$ \\
\hline $\mathrm{O}(4)-\mathrm{N}(2)-\mathrm{O}(3)$ & $123.06(17)$ \\
\hline $\mathrm{O}(4)-\mathrm{N}(2)-\mathrm{C}(3)$ & $118.66(16)$ \\
\hline $\mathrm{O}(3)-\mathrm{N}(2)-\mathrm{C}(3)$ & $118.24(16)$ \\
\hline $\mathrm{O}(6)-\mathrm{N}(3)-\mathrm{O}(5)$ & $123.45(16)$ \\
\hline $\mathrm{O}(6)-\mathrm{N}(3)-\mathrm{C}(5)$ & $119.62(17)$ \\
\hline $\mathrm{O}(5)-\mathrm{N}(3)-\mathrm{C}(5)$ & $116.93(17)$ \\
\hline
\end{tabular}

Table 4. Hydrogen bond parameters in OTP.

\begin{tabular}{ccccc}
\hline $\mathrm{D}-\mathrm{H} \cdots \mathrm{A}$ & $\mathrm{d}(\mathrm{D}-\mathrm{H})$ & $\mathrm{d}(\mathrm{H} \cdots \mathrm{A})$ & $\mathrm{d}(\mathrm{D} \cdots \mathrm{A})$ & $<(\mathrm{DHA})$ \\
\hline $\mathrm{N}(4)-\mathrm{H}(4 \mathrm{~A}) \cdots \mathrm{O}(7) \# 1$ & 0.89 & 1.89 & $2.7697(19)$ & 172.0 \\
$\mathrm{~N}(4)-\mathrm{H}(4 \mathrm{~B}) \cdots \mathrm{O}(5) \# 2$ & 0.89 & 2.14 & $2.853(2)$ & 136.9 \\
$\mathrm{~N}(4)-\mathrm{H}(4 \mathrm{C}) \cdots \mathrm{O}(7)$ & 0.89 & 1.88 & $2.762(2)$ & 172.5 \\
\hline
\end{tabular}

$\# 1 \mathrm{x},-\mathrm{y}+1 / 2, \mathrm{z}+1 / 2 ; \# 2-\mathrm{x}+1,-\mathrm{y},-\mathrm{z}+1$. and cationic o-Toluidinium species is non-planar and is shown in the torsion angle of $\mathrm{N}(1)-\mathrm{C}(1)-\mathrm{C}(2)-\mathrm{C}(3)$, $\mathrm{N}(2)-\mathrm{C}(3)-\mathrm{C}(4)-\mathrm{C}(5), \quad \mathrm{N}(3)-\mathrm{C}(5)-\mathrm{C}(6)-\mathrm{C}(1), \mathrm{N}(4)-\mathrm{C}(7)-$ $\mathrm{C}(8)-\mathrm{C}(13), \mathrm{C}(13)-\mathrm{C}(8)-\mathrm{C}(9)-\mathrm{C}(10), \mathrm{C}(10)-\mathrm{C}(11)-\mathrm{C}(12)-$ $\mathrm{C}(7)$ which are $179.28(16)^{\circ},-178.89(16)^{\circ}, 178.76(16)^{\circ}$, $-0.8(3)^{\circ}, 178.8(2)^{\circ},-0.6(3)^{\circ}$ respectively.

\subsection{UV-Vis-NIR Transmission Studies}

The optical transmission spectrum of OTP crystals was recorded in the region $200-1100 \mathrm{~nm}$ employing a Shimadzu UV-1061 UV-Vis spectrophotometer in solution using DMSO as the solvent. The recorded transmission spectrum of OTP is shown in Figure 7. The lower cutoff wavelength of the OTP crystal was around $488 \mathrm{~nm}$. The attained percentage of transmittance was around 97 for OTP complex in the region between 500 and $1100 \mathrm{~nm}$. Hence, this crystal can be used for the suitable optical applications due to its wide transparency range in the part of visible region above $488 \mathrm{~nm}$ and in the entire near infrared region.

\subsection{Fluorescence Emission Studies}

Fluorescence may be expected generally in molecules that are aromatic or contain multiple conjugated double bonds with a high degree of resonance stability [21].The fluorescence emission spectrum of OTP was recorded using HORIBA JASCO V-670 FLUOROLOG 3 spectrofluorometer. The fluorescence emission spectrum was recorded in the range from 500 to $900 \mathrm{~nm}$ and depicted in Figure 8. Two peaks at 555 and $607 \mathrm{~nm}$ observed in the emission spectrum indicates that OTP crystal has a greenorange fluorescence emission.

\section{Conclusion}

The organic molecular charge transfer complex salt OTP

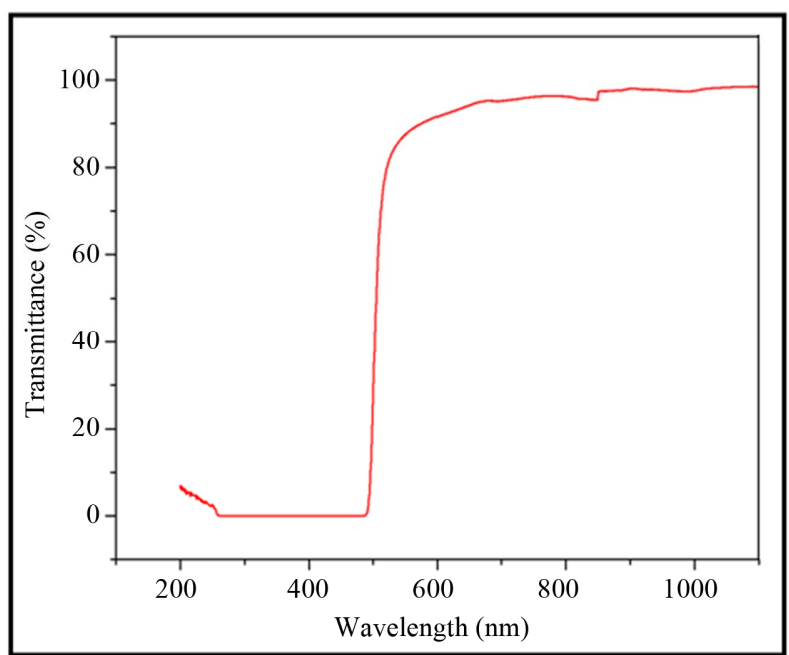

Figure 7. Optical transmission spectrum of OTP. 


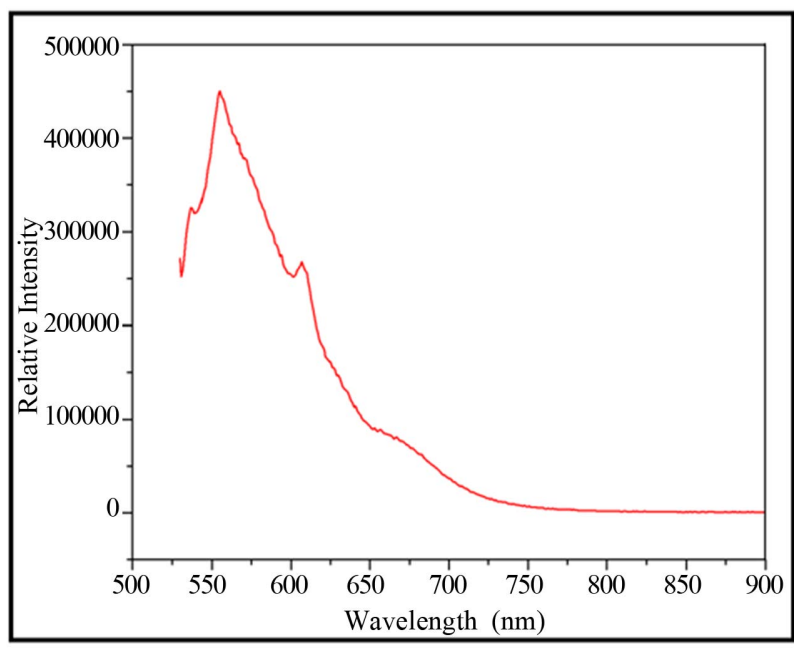

Figure 8. Fluorescence emission spectrum of OTP.

was synthesized and the single crystals of it were grown by slow evaporation solution growth technique using methanol as the solvent. FT-IR, ${ }^{1} \mathrm{H}$ and ${ }^{13} \mathrm{C}$ NMR spectral techniques confirm the molecular structure of OTP and also bring forth the evidence for the prevalent charge transfer activity in the complex salt. The single crystal XRD study reveals that OTP crystallizes in monoclinic crystal system with $\mathrm{P} 2{ }_{1} / \mathrm{c}$ space group. UV-Vis-NIR transmittance study shows that the attained percentage of transmission was around $97 \%$ for OTP complex in the region between $500-1100 \mathrm{~nm}$. Hence the title crystal is a good candidate for suitable optical applications. Fluorescence emission study shows that OTP crystal has a green-orange fluorescence emission.

\section{REFERENCES}

[1] D. Josse, R. Hierle, I. Ledoux and J. Zyss, "Highly Efficient Second Harmonic Generation of Picoseconds Pulses at $1.32 \mu \mathrm{m}$ in 3-Methyl-4-nitropyridine-1-oxide," Applied physics Letters, Vol. 53, No. 23, 1988, pp. 2251-2253. http://dx.doi.org/10.1063/1.100413

[2] B. F. Levine, C. G. Bethea, C. D. Thurmond, R. T. Lynch and J. L. Bernstein, "An Organic Crystal with an Exceptionally Large Optical Second Harmonic Coefficient: 2-Methyl-4-nitroaniline," Journal of Applied Physics, Vol. 50, No. 4, 1979, pp. 2523-2527. http://dx.doi.org/10.1063/1.326248

[3] P. Gunter, "Nonlinear Optics Laboratory," ETH-Honggerberg, Zurich, 2009.

[4] R. Hierle, J. Badan and J. Zyss, "Growth and Characterization of a New Material for Nonlinear Optics: Methyl3-nitro-4-pyridine-1-oxide (POM)," Journal of Crystal Growth, Vol. 69, No. 2-3, 1984, pp. 545-554. http://dx.doi.org/10.1016/0022-0248(84)90366-X

[5] R. S. Milliken, "Structures of Complexes Formed by Halogen Molecules with Aromatic and with Oxygenated Solvents," Journal of American Chemical Society, Vol.
72, No. 1, 1950, pp. 600-608.

[6] M. M. H. Hamed, M. I. Abdel-Hanid and M. R. Mahmoud, "Molecular Complexes of Some N-Aryl-Dithiocarbamates with $\pi$-Electron Acceptors," Monatshefte für Chemie, Vol. 129, No. 2, 1998, pp. 121-127. http://dx.doi.org/10.1007/PL00010148

[7] A. Chandramohan, R. Bharathikannan, V. Kandhavelu, J. Chandrasekaran and M. A. Kandhaswamy, "Synthesis, Crystal Growth, Structural, Thermal and Optical Properties of Napthalene Picrate an Organic NLO Material," Spectrochimica Acta Part A, Vol. 71, No. 3, 2008, pp. 755-759. http://dx.doi.org/10.1016/j.saa.2008.01.036

[8] A. Chandramohan, R. Bharathikannan, M. A. Kandhasamy, J. Chandrasekaran and V. Kandavelu, "Synthesis, Crystal Growth, Spectral, Thermal and Optical Properties of Acenaphthene Picrate," Crystal Research Technology, Vol. 43, No. 1, 2008, pp. 93-98.

[9] A. Chandramohan, R. Bharathikannan, J. Chandrasekaran, P. Maadeswaran, R. Renganathan and V. Kandavelu, "Synthesis, Crystal Growth and Characterization of a New Organic NLO Material: Caffeinium Picrate (CAFP)-A Charge Transfer Molecular Complex Salt," Journal of Crystal Growth, Vol. 310, No. 24, 2008, pp. 5409-5415. http://dx.doi.org/10.1016/j.jcrysgro.2008.09.020

[10] G. A. Babu, S. Sreedhar, S. V. Rao and P. Ramasamy, "Synthesis, Growth, Structural, Thermal, Linear and Nonlinear Optical Properties of a New Organic Crystal: Dimethylammonium Picrate," Journal of Crystal Growth, Vol. 312, No. 12-13, 2010, pp. 1957-1962.

[11] H. Takayanagi, T. Kai, S. Yamaguchi, K. Takeda and M. Goto, "Studies on Picrate. VIII Crystal and Molecular Structures of Aromatic Amine Picrates: Aniline, N-Methylaniline, N, N-Dimethylaniline and o-, $\mathrm{m}$ - and p-Phenylenediamine Picrates," Chemical and Pharmaceutical Bulletin, Vol. 44, No. 12, 1996, pp. 2199-2204. http://dx.doi.org/10.1248/cpb.44.2199

[12] P. Ramesh, R. Akalya, A. Chandramohan and M. N. Ponnusamy, "4-Aminopyridinium Picrate," Acta Crystallographica Section E, Vol. 66, No. 4, 2010, Article ID: O1000. http://dx.doi.org/10.1107/S1600536810011050

[13] K. Muthu and S. Meenakshisundaram, "Crystal Growth, Structure and Characterization of p-Toluidinium Picrate," Journal of Crystal Growth, Vol. 352, No. 1, 2012, pp. 163-166. http://dx.doi.org/10.1016/j.jcrysgro.2011.11.058

[14] C. Muthamizhchelvan, K. Saminathan, J. Fraanje, R. Peschar and K. Sivakumar, "3-Methylanilinium Picrate," Acta Crystallographica Section E, Vol. 61, No. 4, 2005, pp. o1153-o1155.

http://dx.doi.org/10.1107/S1600536805009189

[15] C. Muthamizhchelvan, K. Saminathan, J. Fraanje, R. Peschar and K. Sivakumar, "Crystal Structure of 2-Cholroanilinium Picrate," Analytical Sciences, Vol. 21, No. 4, 2005, pp. x61-x62.

[16] G. Smith, U. D. Wermuth and P. C. Healy, "A Second Crystal Polymorph of Anilinium Picrate," Acta Crystallographica Section E, Vol. 60, No. 10, 2004, pp. o1800o1803. http://dx.doi.org/10.1107/S1600536804022603

[17] V. K. Kumar and R. Nagalakshmi, "Vibrational Spectro- 
scopic Studies of an Organic Non-Linear Optical Crystal 8-Hydroxy Quinolinium Picrate," Spectrochimica Acta Part A, Vol. 66, No. 4-5, 2007, pp. 924-934. http://dx.doi.org/10.1016/j.saa.2006.03.042

[18] G. Anandha Babu, A. Chandramohan, P. Ramasamy, G. Bhagavannarayana and B. Varghese, "Synthesis, Structure, Growth and Physical Properties of a Novel Organic NLO Crystal: 1,3-Dimethylurea Dimethylammounium Picrate," Materials Research Bulletin, Vol. 46, No. 3, 2011, pp. 464-468.

http://dx.doi.org/10.1016/j.materresbull.2010.11.018

[19] A. Chandramohan, R. Bharathikannan, M. A. Kandhas- wamy, J. Chandrasekaran, R. Renganathan and V. Kandavelu, "Synthesis, Spectral, Thermal and NLO Properties of N,N-Dimethyl Anilinium Picrate," Crystal Research and Technology, Vol. 43, No. 2, 2008, pp. 173178.

[20] G. M. Sheldrick, "SHELXL-97, Program for X-Ray Crystal Structure Refinement," University of Gottingen, Gottingen, 1997.

[21] H. H. Willard, L. L. Merritt, J. A. Dear and F. A. Settle, "Instrumental Methods of Analysis," 6th Edition, Wadsworth Publishing Company, Belmont, 1986.

\section{Supplementary Material}

CCDC 894814 contains the supplementary crystallo-graphic data for this paper. These data can be obtained free of charge via www.ccdc.cam.ac.uk/data-request/cif, by e-mailing data-request @ccdc.cam.ac.uk or by contacting The Cambridge Crystallographic Data Centre, 12 Union Road, Cambridge CB21 EZ, UK; Fax: + 441223 336033. 